\title{
Viral gastroenteritis and diversity of rotavirus strains in Colombian children: a systematic review
}

\author{
Delfina Urbina Ospino, Gregorio Young, Octavio Arzuza Navarro. \\ University of Cartagena, Cartagena, Colombia.
}

\begin{abstract}
Background: To determine the epidemiological profile of viruses associated with acute gastroenteritis in children younger than 5 years of age and the distribution of rotavirus genotypes circulating in Colombia.

Methodology: We conducted a review of 23 studies published in Spanish and English, plus an analysis of the detection rates of rotavirus as well as other viruses associated with acute gastroenteritis in young children from 1984 to 2006 in the three Colombian regions. This review also included the only two studies conducted to date (published between 2004 and 2006) reporting G-P rotavirus strains using RT-PCR.

Results: The median detection rate of group A Rotavirus was 35.2\% (range, $2.2 \%-57.4 \%$ ) and those for Calicivirus, Astrovirus and Adenovirus 40/41 were $10.4 \%, 2.7 \%$ and $1.35 \%$, respectively. The more commonly reported rotavirus GP combination, G3P [8] (32.7\%) was more frequently documented than both G1P [8] (24.7\%) and G2P [4] (22.9\%). The G9 genotype, which is considered emergent, was also reported.

Conclusions: Group A Rotavirus was frequently associated with diarrhoea in children from the three regions. There was regional variation in rotavirus detection rates. Continual surveillance is needed to inform diarrhoea prevention programs as well as to provide information about the occurrence of native rotavirus strains.
\end{abstract}

Key Words: Gastroenteritis, Rotavirus, Calicivirus, Astrovirus, Adenovirus, Genotypes.

J Infect Developing Countries 2008; 2(2):99-105.

Received 31 July 2007 - Accepted 12 February 2008.

Copyright (c) 2007 Urbina et al. This is an open access article distributed under the Creative Commons Attribution License, which permits unrestricted use, distribution, and reproduction in any medium, provided the original work is properly cited.

\section{Introduction}

Acute gastroenteritis is a common disease worldwide. It is also estimated that diarrhoeal disease is a major cause of morbidity and mortality among children globally, particularly in nonindustrialized countries. In industrialized countries, diarrhoeal diseases are a significant cause of morbidity due to outbreaks across all age groups [1].

Since the 1940s, investigators have considered viruses as potential agents of gastroenteritis [2] and enteric viruses were first discovered in the 50s and 60s. However, early studies did not find any of these agents to be associated with diarrhoeal disease. The stalemate ended with the discovery of the Norwalk virus and its association with epidemic gastroenteritis in young children and adults by Kapikian et al., in 1972 [3]. In 1973, Bishop et al. discovered the human Rotavirus and its association with severe endemic diarrhoea in infants and older children [4].
Since that time, the number of viruses associated with acute gastroenteritis occurring in pediatric patients has constantly increased. In 1975 Astrovirus (AstV) and enteric Adenovirus (AdV) 40/41 were detected in feces from pediatric patients with acute diarrhoea [2]. Both rotavirus (RV) and Calicivirus (CV) are responsible for a large number of infantile gastroenteritis cases. Group C rotaviruses (RVC), Coronavirus, Picobirnavirus, Pestivirus and Torovirus, considered primary agents of gastroenteritis among animal species, are now recognized as emergent viruses associated with viral gastroenteritis in human patients [2,5].

Viral acute gastroenteritis is more frequent than both bacterial and parasitic diarrhoea, causing high morbidity as well as mortality in children in developing countries. In industrialized countries, morbidity occurs mostly as outbreaks in young children attending day care centers and in the elderly [2]. Type A Rotavirus (RVA) is the most frequent etiologic agent of gastroenteritis in 
children under 5 years of age. Each year, RVA causes approximately 111 million episodes of gastroenteritis requiring only home care, 25 million clinic visits, 2 million hospitalizations, and 352,000592,000 deaths (median, 440,000 deaths) in children under five years of age [6]. A report in Colombia estimated that RVA caused 1 death/ 2.000 children, 16 hospitalizations and 631 clinic visits per each 1,000 children in 2004 [7].

Notwithstanding the large burden of diarrhoeal disease in young children in Colombia, there is little information concerning the real impact of viral gastroenteritis. This article aims to analyze the infection rates of rotavirus and other enteric viruses from data collected between 1984 and 2006, as well as the distribution of usual and unusual G-P rotavirus genotypes in Colombian children with acute gastroenteritis.

\section{Materials and Methods}

Colombia is a tropical country located in the northwest region of South America and is divided into five different natural continental regions and one natural maritime region, each presenting their own unique characteristics. These regions can be described as follows: 1) the Atlantic Northern Coast region (pertaining to the area contiguous to the Caribbean sea), located on the northernmost part of the country where the rainfall levels reach between 500 and 2,000 $\mathrm{mm}$ per year, making this zone one of the country's driest; 2) the West Pacific region (contiguous to the Pacific Ocean which borders with the Pacific ocean), one of the rainiest and most bio-diverse areas of the planet, receiving from 3,000 to $12,000 \mathrm{~mm}$ of rain per year; 3) the Andean region which is formed by Colombia's three mountain systems (pertaining to the Andes), where the rainfall levels range from $1,500 \mathrm{~mm}$ per year in the inner Andean valleys to $4,000 \mathrm{~mm}$ per year in the higher Andean forests and mountains; 4) the Orinoquia region, which borders with Venezuela to the west and is mainly plain; and 5) the Amazonic region (the southernmost part of Colombia bordering Brazil, Ecuador and Peru), which is conformed by the Amazon rain forest. Exceptionally variable rainfall levels can be seen, ranging from $1,500 \mathrm{~mm}$ per year up to $3,500 \mathrm{~mm}$ in Orinoquia to 3,000 to $4,000 \mathrm{~mm}$ per year in the Amazonic region. The Insular Region comprises the areas outside the continental territories, including the San Andrés y
Providencia Department in the Caribbean Sea and the Malpelo and Gorgona Islands in the Pacific Ocean (Figure 1).

For this review, we examined each study based on the availability of reports on international databases (Medline and Lilacs), and other serial publications within the country. We included studies in Spanish and English published from 1984 to 2006 [7,8-25], which have fulfilled the following requirements:

Figure 1. Natural Regions of Colombia: Continental (Northern coast / Atlantic, Andean/Central, West Pacific, Orinoquia and Amazonic) and insular regions (Atlantic and Pacific oceans). Adapted from http://www.memo.com.co/fenonino/aprenda/geografia/ regiones.html, accessed April 24, 2008.

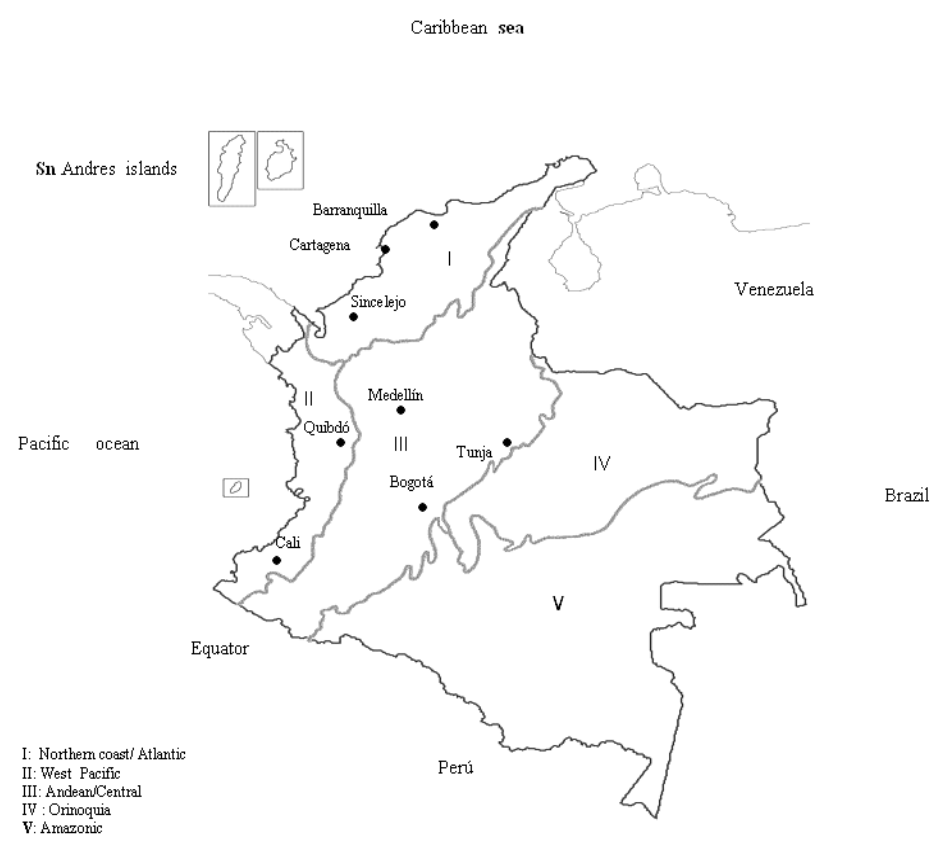

a) The study included children younger than 5 years of age, with acute diarrhoea as established by the World Health Organization (WHO)

b) The study used standardized laboratory techniques for identification and typing of viral agents. All methods considered included the enzyme-linked immunosorbent assay (ELISA), polyacrylamide gel electrophoresis (PAGE), latex agglutination (LA), and the reverse transcription polymerase chain reaction (RT-PCR)

From the selected studies we extracted information on the detection rates of $R V, C V$, AstV and AdV; the year and site of study; the 
method used; and the ages of the children enrolled. The study included children from cities and townships located at 2.0 to 2,800 meters above sea level (m.a.s.l.) in three Colombian regions (Table 1). The detection rates were examined separately to determine the medians of each virus, except for RVC.

We also considered the two studies on RVA genotypes up to now, (published between 2004 and 2006) which examined $>50$ rotavirus samples and tested them for both $G$ and $P$ types by means of RT-PCR [7, 26]. The results of these studies were tabulated to examine the frequency of individual $G$ and $P$ rotavirus genotypes, as well as G-P common (G1P[8], G2P[4] G3P[8]) and G4 [8]) and the remaining uncommon strains.

Table 1. Geographical and atmospheric factors in cities from three Colombian regions.

\begin{tabular}{|c|c|c|c|c|c|}
\hline Regions & Cities & M.A.S.L. & $\mathrm{T}^{\circ} \mathrm{C}$ & Latitude & Longitude \\
\hline & Bogotá & 2.640 & 12.9 & $4^{\circ} 39^{\prime} 0^{\prime} \mathrm{N}$ & $74^{\circ} 3^{\prime} 0^{\prime} \mathrm{W}$ \\
\hline \multirow[t]{3}{*}{$\begin{array}{l}\text { Andean } \\
\text { /Central }\end{array}$} & Facacativá & 2586 & 14 & & \\
\hline & Tunja & 2.810 & 14 & $5^{\circ} 32 \mathrm{~N}$ & $73^{\circ} 22^{\prime} \mathrm{W}$ \\
\hline & Medellín & 1.538 & 22,5 & $6^{\circ} 15^{\prime} \mathrm{N}$ & $75^{\circ} 36^{\prime} \mathrm{W}$ \\
\hline $\begin{array}{l}\text { Northern } \\
\text { Coast / }\end{array}$ & Cartagena & 2.0 & 27 & $10^{\circ} 26^{\prime} 33^{\prime \prime} \mathrm{N}$ & $75^{\circ} 30^{\prime} 58^{\prime \prime} \mathrm{W}$ \\
\hline \multirow[t]{2}{*}{ Atlantic } & Barranquilla & 5.0 & 28 & $10^{\circ} 57^{\prime} 50 " \mathrm{~N}$ & $074^{\circ} 47^{\prime} 47^{\prime \prime}$ \\
\hline & Sincelejo & 213 & 27 & $998^{\prime} \mathrm{N}$ & 7524 ' W \\
\hline \multirow[t]{2}{*}{$\begin{array}{l}\text { West } \\
\text { Pacific }\end{array}$} & Cali & 995 & 23 & $3^{\circ} 27^{\prime} 0^{\prime} \mathrm{N}$ & $76^{\circ} 32^{\prime} 0^{\prime} \mathrm{W}$ \\
\hline & Quibdó & 43 & 28 & $5^{\circ} 41^{\prime} 13^{\prime \prime} \mathrm{N}$ & $76^{\circ} 39^{\prime} 40^{\prime \prime} \mathrm{W}$ \\
\hline
\end{tabular}

\section{Results}

Detection rates of RVA, RVC, CV, AstV and AdV from 23 studies reviewed are listed in Table 2 $[7,8,25]$. Overall, RVA was the most prevalent pathogen detected in a median of $35.5 \%$ of the children. The detection rates for the enteric viruses and the distribution of RVA G-P genotypes were as follows:

Andean/Central region: In Bogotá, RVA was detected in a median of $32.0 \%$ of children $[7,11,13,15-17,19]$, and AdV 40/41 in a median of 9.6\% [13,16]. In Facacativá near Bogotá, the detection rate of RVC was 20.2\%; RVA, AdV 4041 and AstV were detected in a median of $15.5 \%$,
$1.8 \%$ and $2.6 \%$ of children. In the cities of Medellín and Tunja, the RVA detection medians among children were $48.0 \%$ and $48.1 \%$ respectively.

Northern coast/Atlantic Region: RVA, AstV and AdV detection rate medians among children in Cartagena were respectively $30.15 \%, 2.9 \%$ and $1.45 \%$, [10,14,20,23]. In Sincelejo, the RVA detection rate in children was $28.3 \%$ [20] and in Barranquilla, it was $49.5 \%$ [7,12]. Interestingly, there was a gastroenteritis outbreak involving CV, in May and June, 2004, in Barranquilla; however, the detection rates of CV, AstV and AdV 40/41 were not reported in that city [7].

Table 2. Detection rates of RVA, RVC, CV, AdV 40/41 and AstV from 23 studies (published from 1984 to 2006) of children with acute diarrhoea in Colombian regions.

\begin{tabular}{|c|c|c|c|c|c|c|c|}
\hline \multirow[b]{2}{*}{$\begin{array}{l}\text { Years } \\
\text { of } \\
\text { study }\end{array}$} & \multirow[b]{2}{*}{ City } & \multicolumn{4}{|c|}{$\%$ of positive cases with } & \multirow[b]{2}{*}{$R V C$} & \multirow[b]{2}{*}{ Reference } \\
\hline & & $R V A$ & $C V$ & $\begin{array}{l}A d V / \\
4041\end{array}$ & AstV & & \\
\hline $\begin{array}{c}1979- \\
1980\end{array}$ & Medellín & 35.5 & & & & & 9 \\
\hline 1982 & Medellín & 48.0 & & & & & 10 \\
\hline $\begin{array}{c}1982- \\
83\end{array}$ & Cartagena & 20.0 & & & & & 11 \\
\hline $\begin{array}{c}1983- \\
84\end{array}$ & Bogotá & 51.1 & & & & & 12 \\
\hline 1984 & Barranquilla & 55.5 & & & & & 13 \\
\hline 1988 & Bogotá & 2.21 & & 0.7 & & & 14 \\
\hline 1994 & Cartagena & 35.0 & & & & & 15 \\
\hline 1994 & Bogotá & 14.3 & & & & & 16 \\
\hline $96-98$ & Bogotá & 32.0 & & 18.5 & & & 17 \\
\hline 1997 & Bogotá & 19.7 & & & & & 18 \\
\hline $\begin{array}{c}1997- \\
99\end{array}$ & Bogotá & & & & 5.0 & & 19 \\
\hline $\begin{array}{c}1997- \\
99\end{array}$ & Medellín & 48.0 & & & & & 20 \\
\hline $\begin{array}{l}1998- \\
2000\end{array}$ & Cartagena & 44.2 & & & & & 21 \\
\hline $\begin{array}{l}1998- \\
2000\end{array}$ & Sincelejo & 28.3 & & & & & 21 \\
\hline $\begin{array}{c}2000- \\
01\end{array}$ & Bogotá & 43.0 & & & & & 22 \\
\hline $\begin{array}{l}1999- \\
2000\end{array}$ & Facacativá & 13.0 & 10.0 & 2.3 & 2.7 & 20.2 & 23 \\
\hline $\begin{array}{c}2002- \\
03\end{array}$ & Facacativá & 18.0 & & 1.26 & 2.5 & & 23 \\
\hline $\begin{array}{c}2002- \\
03\end{array}$ & Cartagena & 24.8 & & 1.45 & 2.9 & & 24 \\
\hline $\begin{array}{c}2000- \\
03\end{array}$ & Quibdó & 8,14 & 10.8 & 0.45 & 1.3 & & 25 \\
\hline $\begin{array}{c}2003- \\
04\end{array}$ & Bogotá & 51.8 & & & & & 7 \\
\hline $\begin{array}{c}2003- \\
04\end{array}$ & Cali & 57,4 & & & & & 7 \\
\hline $\begin{array}{c}2003- \\
04\end{array}$ & Barranquilla & 43,6 & & & & & 7 \\
\hline 2004 & Tunja & 48.1 & & & & & 26 \\
\hline Median & & 35.2 & 10.4 & 1,35 & 2.7 & & \\
\hline Range & & $\begin{array}{l}(2.2- \\
57.4) \\
\end{array}$ & $\begin{array}{c}(10.0- \\
10.8) \\
\end{array}$ & $\begin{array}{c}(0.45- \\
18.5) \\
\end{array}$ & $\begin{array}{c}(1.3- \\
5.0)\end{array}$ & & \\
\hline
\end{tabular}

West Pacific region: the RVA detection rate was reported to be more prevalent in Cali than in 
Quibdó, where the detection rates of RCV and RVA were quite similar [7,25] (Table 2).

Distribution of common and uncommon RVA G- $P$ combinations: A total of 283 rotavirus strains were analyzed for the relative frequency of various RVA genotypes reported in two separate studies. Two hundred forty-three children from Cartagena and Sincelejo (Northern coast and Atlantic regions), were enrolled in the first study [26], and 726 children from Bogotá, Cali and Barranquilla (Andean/Central, West Pacific and Northern coast/Atlantic regions), were included in the second study [7].

As shown in Figure 2, rotavirus strains from three common rotavirus G-P combinations, (G1P[8], G2P[4] and G3P[8]), were responsible for $79.4 \%$ of the rotavirus diarrhoea cases among
In 2002-2003, three of the most common G-P combinations (G1P [8], G2P [4] and G3P [8]) represented $72.9 \%$ of strains and the uncommon G-P combinations accounted for $15.0 \%$. The detection rate of G1P [8] was $19.1 \%$. The rates of individual genotypes were not reported in that city [7].

In general, the detection rates of untypeable rotavirus strains ranged from $7.5 \%$ to $32.2 \%$, and the index of rotavirus mixed infections remained between $8.5 \%$ and $21.0 \%[7,26]$.

\section{Discussion}

This review provides general information on the behavior of viruses associated with gastroenteritis in children in our settings, and the distribution of native RVA strains circulating in the

Figure 2. RVA Genotypes detected in Colombian children with acute gastroenteritis in the Northern coast/Atlantic region (1998-2000) and in the Andean/Central, West Pacific, and Northern coast/Atlantic regions (2003-2004).

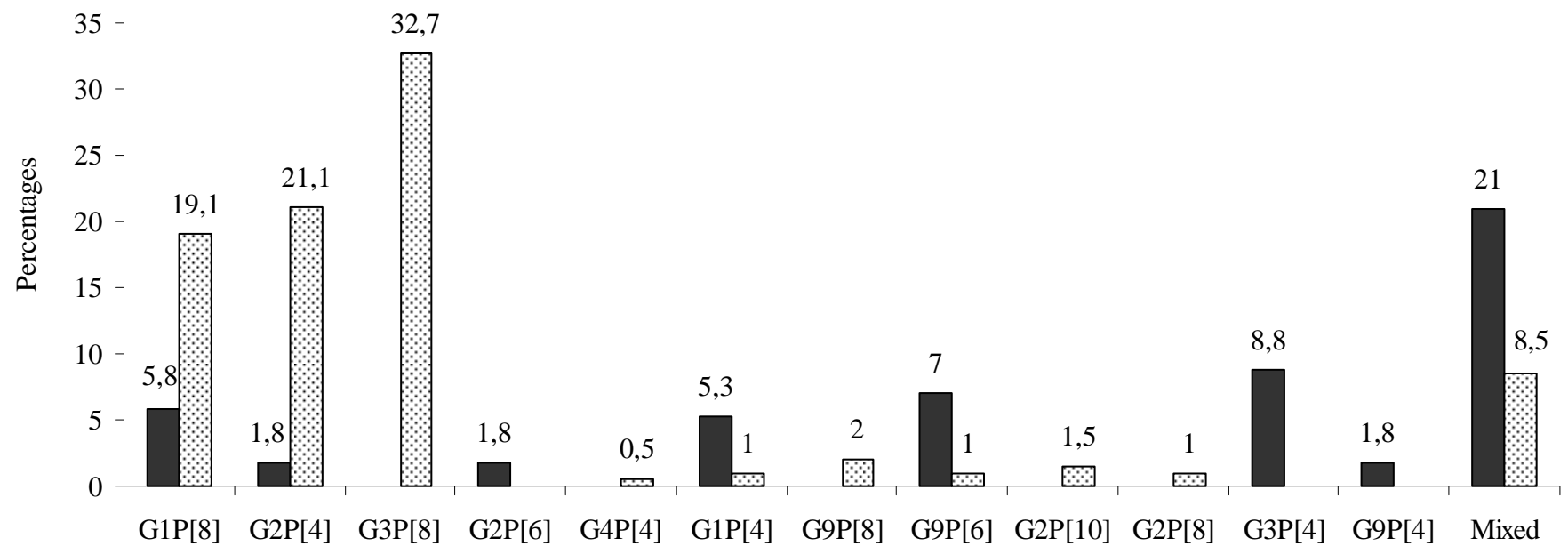

1998-00 (Ref: 27) 2003-04 (Ref: 7)

young children in Colombia. In Cartagena and Sincelejo (1998-2000), G1P [8] and G2P[4] represented only $7.6 \%$ of the strains; G3P[8] was undetected. In contrast, other G-P combinations were responsible for $45.7 \%$ of rotavirus diarrhoea cases.

Among individual genotypes, it was found that G1 (57.9\%) was predominant, followed by G3 (21.1\%), G9 (15.8\%) and G2 (5.3\%). With respect to $P$ genotypes, $P$ [4] (49.1\%) was more prevalent than both $P$ [6] (36.4\%) and P[8] (14.5\%). three regions of Colombia (with marked climatologic and geographical distinctions) as we face the need for a surveillance program and future studies in order to measure the impact of current and upcoming rotavirus vaccination efforts.

First, regarding the rates of viruses associated with diarrhoea cases, there was an overall predominance of RVA except for two settings (Facacativá and Quibdó) in the Andean/Central and West Pacific regions. It is important to point out that the median detection rate of $35.5 \%$ for RVA was slightly higher than the $31.0 \%$ and $30.5 \%$ 
medians reported by $\mathrm{E}$. Khane et al. in other Latin American children [27].

The average detection rates of CV (10.4\%), AstV (2.7\%) and AdV 40/41 (1.4\%) were comparable to those reported $(14.0 \%, 3.0 \%$ and $6.0 \%$ ) in industrialized and non-industrialized countries [28 -33]. Otherwise, the RVC detection rate reported in Facatativá, was higher than those reported in Argentina (1.02 \%) [34] and Japan (6.8 \%) [35].

We were unable to establish an association between altitude and the frequency of certain diarrhoea-causing agents. Seemingly, as a possible connection was indicated by some reports [23], the association may be more closely linked to climatologic conditions such as dry or rainy seasons.

Secondly, with respect to the diversity of G-P rotavirus strains, the two studies showed a large variety of GP rotavirus strains circulating in Colombia. G9 first appeared in Cartagena in the Northern Coast/Atlantic region in 1998-2000 [26]. Two years later, the G9 genotype was also reported in Bogotá and Cali, located 1.090 and $1.500 \mathrm{~km}$ away from Cartagena.

The appearance of these two strains relates to the emergence of association with both common and uncommon P genotypes G9P[6], G9P[8] and G9P[4] in the three regions (Figure 2). This finding reinforces the necessity for widespread and continued investigations of rotavirus strains in Colombia.

G9 strains were first described in Philadelphia, PA, USA (1983-1984); they were undetected for about one decade, and then re-emerged in the same city in 1995-1996, and thereafter expanded worldwide [36]. G9 is the third genotype in terms of impact in some places [37,38]. Geographic fluctuation of various common rotavirus G-P strains is seen at continental and sub-continental levels. The frequency of the G1P [8] genotype in Europe and in the US, for instance, is over $72 \%$, while in South America and in the African continent the frequency of this strain decreases to almost half of the above percentage.

The frequency of G1P [8] in Bogotá (36.9\%) was twice as high as that in Cali (18.4\%). In addition there was a previous report of 14 individual genotypes ( $G 1$ and $P 8$, each) in Facatativá [22]. This suggests that the G1P [8] strain is predominant in the Andean/Central region.
However, the diminished frequency of G1P[8] in cities on the Northern coast /Atlantic region, 5.3\% in Cartagena and $4.1 \%$ in the city of Barranquilla, must be kept in mind whenever a vaccination program is to be put in place in this region.

Interestingly, the incidence of mixed rotavirus infection reported in the Northern /Atlantic Coast [26] was similar to those in Brazil and in India with detection rates of $16.0 \%, 21.0 \%$ and $24 \%$ $[37,39,40]$. Nonetheless mixed infections in the Northern Atlantic Coast region was higher than recently reported from the other Colombian regions [7].

Diversity and geographical distribution of RVA strains have been widely analyzed due to the implications of current and future vaccines [6,36,41-43]. In Latin American countries, including Colombia, the Rotarix vaccine based on an attenuated G1 [P8] strain, has shown clinical efficacy against severe diarrhoea and was not associated with an increased risk of intussusception [44-46]. However, Rotarix and other vaccines need to reach protection against rotavirus strains from different genogroups and studies of this nature could determine which principal genogroups should be prioritized [41]. In summary, for over two decades the search for agents associated with acute diarrhoea/gastroenteritis among children in Colombia showed that RVA is the most prevalent agent. We consider that the search for RVA must be widened through other Colombian regions and the diversity of rotavirus strains must be evaluated to assure a successful vaccination program along and across the entire country.

\section{References}

1. Grupka, MJ Wu, G "Gastroenteritis, Viral" In: Lee JG; Talavera F, WIliams M.; illiams, MD; Mechaber AJ and Katz J (eds) eMedicine Specialties. Available: http://www.emedicine.com/specialties.htm. Accessed, December 2006.

2. Wilhelmi I, Roman E, Sanchez-Fauquier A. (2003) Viruses causing gastroenteritis. Clin Microbiol Infect. 4: 247-262.

3. Kapikian AZ, Hoshino Y, Chanock RM (2001) Rotaviruses. In: Fields BN et al. (eds) Fields' Virology 4th ed. Lippincott Williams and Wilkins, Philadelphia, PA, pp.1787-1802.

4. Estes MK (2001) Rotaviruses and their replication. In: Fields BN et al. (eds) Fields' Virology 4th ed. Lippincott Williams and Wilkins, Philadelphia, PA, pp 1747-1758).

5. Eiros JM, Bachiller MR, Ortiz de Lejarazu R (2001) Ribovirus emergentes implicados en la gastroenteritis. An Esp Pediatr 54: 136 - 144. 
6. Parashar UD, Hummelman EG, Bresee JS, Miller MA, Glass RI (2003) Global Illness and Deaths Caused by Rotavirus Disease in Children. Emerg. Infect. Dis 9:565572.

7. Cáceres DC, Peláez D, Sierra N., Estrada E, Sánchez L (2006) La carga de la enfermedad por rotavirus en niños menores de cinco años, Colombia, 2004. Rev Panam Salud Publica. 20: 9-21.

8. Arango AE, Aguirre C, Aristizabal L, Hanssen H (1985) Frecuencia de rotavirus en niños menores de cinco años con diarrea aguda: Primer Informe; estudio en un grupo de niños de la ciudad de Medellín. Salud Uninorte 2: 129-138 (Article in Spanish).

9. Trujillo H, Jaramillo C, Restrepo M, Mejía GI, Zapata CT, Ramírez R, Betancourt R (1985) Rotaviruses and other enteropathogens in the etiology of acute diarrea in edellín, Colombia. Bol Oficina Sanit Panam 98: 251-260 (Article in Spanish).

10. Urbina D, Cortés A (1984) Determinación de Rotavirus en niños con enfermedad diarreica aguda. Ciencia Tecnol Educ 6:27-38 (Article in Spanish).

11. Leal F (1985) Agentes Epidemiológicos de la Diarrea Aguda en Bogotá. Pediatria 21: 8-32. (Article in Spanish).

12. Remolina A et al. (1985) La enfermedad diarreica aguda (EDA): estudios epidemiológicos en el departamento del Atlántico, Colombia. Salud Uninorte 2: 71-79. (Article in Spanish).

13. Mora J, Juliao O, Suescun J, Guzman M (1988) Estudio longitudinal sobre la epidemiología y la etiología de la enfermedad diarreica aguda en los niños de una comunidad urbana de Bogotá, Colombia. Escuela Colombina de Medicina 1: 93-120 (Article in Spanish).

14. Urbina D, Young G, Torres I Diarrea por Rotavirus. (2000) Ciencias Médicas Universidad Cartagena. 1: 6-12 (Article in Spanish).

15. Guerrero CA, Moreno LP, Peñaranda J, Acosta O.(1994) Caracterización electroferotípica de rotavirus aislados con gastroenteritis en la ciudad de Bogotá. Rev Fac Med. UN Col 42: 203-208 (Article in Spanish).

16. Gutiérrez MF, Serrano $P$, Vanegas CA, Macías A, Riaños M (2000) Efecto de las variaciones Climáticas en Gastroenteritis causadas por Rotavirus y Adenovirus en niños menores de cuatro años en Santafé de Bogotá entre Junio de 1996 y Junio de 1998. Medicas UIS 14: 24-29 (Article in Spanish).

17. Mattar S, Pulido N, Mulett R, Londoño D, Medina G, Martínez M, Coronado C, Gamboa A (1999) Aetiology of acute infectiuos diarrhoea in a private hospital in Colombia. Med Sci Res 27:29-32.

18. Medina. SM, Gutierrez MF, Liprandi F, Ludert JE (2000) Identification and type distribution of Astrovirus among children with gastroenteritis in Colombia and Venezuela. J Clin Microbiol 38: 3481-3483.

19. Bernal C, Zapata CT, Durango HE, Álvarez CM (2002) Agentes etiológicos de diarrea en niños atendidos en la Unidad de Capacitación para el Tratamiento de la Diarrea del Hospital Universitario San Vicente de Paúl de Medellín. Infectio 6:204-211 (Article in Spanish).

20. Urbina D, Arzuza O, Young G, Parra E, Castro R, Puello M (2003) Rotavirus type A and other enteric pathogens in stool samples from children with acute diarrhea on the Colombian northern coast. Int Microbiol. 6:27-32.
21. Cáceres DC, Estrada E, De Antonio R, Peláez D (2005) La enfermedad diarreica aguda: un reto para la salud pública en Colombia. Rev Panam Salud Publica 17: 6-14. (Article in Spanish).

22. Gutierrez MF, Matiz A, Trespalacios AA, Parra M, Riaño M, Mercado M (2006) Virus diversity of acute diarrhea in tropical highlands. Rev Latinoam Microbiol 48: 17-23.

23. Gutierrez MF et al. (2006) Comportamiento de la diarrea causada por virus y bacterias en regiones cercanas a la zona ecuatorial. Colomb Med 36 (Supl) 1: 6-14 (Article in Spanish).

24. Martínez L, Matiz A, Trespalacios AA, Ajami N, Mora Cl., Serrano P, Mercado M, Gutiérrez MF (2005) Etiología de la enfermedad diarreica aguda en niños menores de 5 años en la población de Quibdo. El Calicivirus, un nuevo hallazgo. Pediatría 40: 43-52. (Article in Spanish).

25. Manrique, FG, Tigne DB, Bello SE, Ospina JM (2006) Agentes causantes de Diarrea en Niños Menores de 5 Años en Tunja, Colombia. Rev. Salud pública 8: 88-97. (Article in Spanish).

26. Urbina D, Rodríguez JG, Arzuza O, Parra E, Young G, Castro R, Del Portillo P (2004) G and P genotypes of rotavirus circulating among children with diarrhea in the Colombian northern coast Int Microbiol 7:113-120.

27. Kane EM, Turcios RM, Arvay ML, Garcia S, Bresee JS, GlassRI (2004) The epidemiology of rotavirus diarrhea in Latin America. Anticipating rotavirus vaccines. Rev Panam Salud Publica. 16:371-377.

28. Bon F et al. (1999) Prevalence of Group A Rotavirus, Human Calicivirus, Astrovirus, and Adenovirus Type 40 and 41 Infections among Children with Acute Gastroenteritis in Dijon, France. J Clin. Microbiol 37: 3055-3058.

29. Ko GP et al. (2005) Noroviruses as a cause of traveler's diarrhea among students from the United States visiting Mexico. J Clin Microbiol 43:126-129.

30. Simpson R, Aliyu S, Iturriza-Gomara M, Desselberger U, Gray J (2003) Infantile viral gastroenteritis: on the way to closing the diagnostic gap. J Med Virol 70: 258-62.

31. Ike AC, Brockmann SO, Hartelt $\mathrm{K}$, Marschang RE, Matthias Contzen M, Oehme RM (2006) Molecular. Epidemiology of Norovirus in Outbreaks of Gastroenteritis in Southwest Germany from 2001 to 2004. J Clin Microbiol 44: 1262-1267.

32. Phan TG et al. (2004) Virus diversity and an outbreak of group $\mathrm{C}$ rotavirus among infants and children with diarrhea in Maizuru city, Japan during 2002-2003. J Med Virol. 74:173-179.

33. Barnes GL, Uren E, Stevens KB, Bishop RF (1998) Etiology of acute gastroenteritis in hospitalized children in Melbourne, Australia, from April 1980 to March 1993. J Clin Microbiol 36:133-138.

34. Castello AA, Arguelles $M H$, Villegas GA, Olthoff A, Glikmann $G$ (2002) Incidence and prevalence of human group $\mathrm{C}$ rotavirus infections in Argentina $\mathrm{J}$ Med Virol 67:106-112.

35. Kuzuya M, Fujii R, Hamano M, Yamada M, Shinozaki K, Sasagawa A. (1998) et al. Survey of Human Group C Rotaviruses in Japan during the Winter of 1992 to 1993. J Clin Microbiol 36: 6-10. 
36. Santos N, Hoshino $Y$ (2005) Global distribution of rotavirus serotypes/ genotypes and its implication for the development and implementation of an effective rotavirus vaccine. Rev Med Virol. 15:29-56.

37. Jain V, Das BK, Bhan MK, Glass RI, Gentsch JR, The Indian Strain Surveillance Collaborating Laboratories. (2001) Great diversity of group A rotavirus strains and high prevalence of mixed rotavirus infection in India. J Clin Microbiol. 39:3524-3529.

38. Bok K, Palacios G, Suvarger K, Matson D, Gómes J (2001) Emergente of G9P[6 ] Human Rotaviruses in Argentina: Pylogenetic Relationships among G9 strains. J Clin Microbiol 39:40-20-4025.

39. Santos N, Lima RC, Pereira CFA, Gouvea V (1998) Detection of rotavirus types G8 and G10 among Brazilian children with diarrhea. J Clin Microbiol 36:2727-2729.

40. Das $S$ et al. (2002) Genomic diversity of group A rotavirus trains infecting humans in Eastern India. J Clin Microbiol 40:146-149.

41. Gentsch JR et al. (1996) Review of $G$ and $P$ typing results from a global collection of rotavirus strains: implication for vaccine development. J Infect Dis 174: S1:30-36.

42. Castello AA, Arvay ML, Glass RI, Gentsch G (2004) Rotavirus Strain Surveillance in Latin America. A Review of the Last Nine Years. Pediatr Infect Dis J 23: S168S172.

43. Urbina Delfina. Epidemiology of Rotavirus: Genotypes Serotypes. Available: www.oloep.org Accessed 15 January 2006.

44. CDC (2006) Prevention of Rotavirus Gastroenteritis among Infants and Children: Recommendations of the Advisory Committee on Immunization Practices (ACIP). NMWR. 55 / RR-12: 3-4.

45. Ruiz-Palacios GM, et al. (2006) Safety and Efficacy of an Attenuated Vaccine against Severe Rotavirus Gastroenteritis. N Engl J Med 354: 11-22.

46. López P. Vacuna contra Rotavirus: Desarrollo, Seguridad, Eficacia. Available: http://colombiamedica.univalle.edu.co/MEMORIAS.pdf. Accessed, March 2007.
Corresponding Author: Delfina Urbina, Manga. Calle 28 № 21-128 Edifico Barbacoa Apto 104, Cartagena, Colombia. Tel: 57-5-660-70-46, Fax: 57-5-660-70-46. Email: delurbina@yahoo.com.

Conflict of interest: No conflict of interest is declared. 